\title{
Membangun Politik Hukum Asas Legalitas dalam Sistem Hukum Pidana Indonesia
}

\author{
Faisal \\ Fakultas Hukum Universitas Bangka Belitung \\ Jl. Balunijuk, Pangkalpinang, Bangka Belitung \\ progresif_lshp@yahoo.com
}

\begin{abstract}
This research is to discuss: first, what accounts for the reconceptualization of legality; and second, how to establish the legality principle law politics based on the social conditions of Indonesian society. This research is a normative legal study using the primary and secondary legal sources. This study concludes that first there is an adoption of characteristics which are against the formal law in legality principles of Criminal Code, namely the provision stating that a crime does exist in case of the fulfilment of the elements stated in the descriptiom of the case or accompanied by the consequences, which show that there is no place for unwritten law (customs) by looking at the existence of the characteristics of formal law violation. Second, ideas, concepts, values, of balance are the significant support in the legal political attempt of the legality principle using the prismatic concept (equilibrium value). The legality prismatic concept of the legality principle is originated from and oriented to the equilibrium of five pillars of Pancasila, which can be compacted into "three pillar equilibrium", those are religion pillar, humanity pillar, and social pillar (nationalism, democracy, and social justice).
\end{abstract}

Key words : Legality principle, law politics, equilibrium idea, legal prismatic.

\begin{abstract}
Abstrak
Penelitian ini mengangkat permasalahan: pertama, apakah yang mendasari untuk dilakukan rekonseptualisasi terhadap asas legalitas? Kedua, bagaimana membangun politik hukum asas legalitas berdasarkan pada kondisi sosial masyarakat Indonesia? Penelitian ini adalah penelitian hukum normatif, yang menggunakan bahan hukum primer serta bahan hukum sekunder. Penelitian ini menyimpulkan, pertama, dianutnya ajaran sifat melawan hukum formal dalam asas legalitas KUHP yakni ajaran yang mengatakan bahwa suatu tindak pidana telah terjadi apabila telah terpenuhi unsurunsur seperti yang termuat dalam lukisan delik atau disertai akibat-akibatnya, menunjukkan tidak ada tempat bagi hukum yang tidak tertulis (kebiasaan) bila melihat keberlakuan ajaran sifat melawan hukum formal. Kedua, gagasan, konsep, nilai, dan ide keseimbangan merupakan sokongan yang berarti dalam melakukan upaya politik hukum asas legalitas dengan tawaran konsep prismatik (nilai keseimbangan yang baik). Dimana prismatika hukum asas legalitas bersumber dari dan berorientasi pada keseimbangan lima sila dalam Pancasila, yang dapat dipadatkan menjadi "keseimbangan tiga pilar", yaitu; pilar ketuhanan (religius), pilar kemanusiaan (humanistik) dan pilar kemasyarakatan (kebangsaan, demokrasi, dan keadilan sosial).
\end{abstract}

Kata kunci: Asas legalitas, politik bukum, ide keseimbangan, prismatika bukum 


\section{Pendahuluan}

Hukum bukan hanya sekedar teks yang absolut ketika otoritas negara telah memberikan legitimasi kepadanya. Lebih dari itu, hukum merupakan cermin dari formalisasi dan kristalisasi kehendak masyarakat. Tidak terkecuali hukum pidana sekalipun, yang tidak dapat menghindar dari situasi serta interaksi masyarakatnya.

Abad modern membangun legitimasi hukum melalui dominasi rasionalitas teks. ${ }^{1}$ Penyajian teks menjadi sesuatu yang agung memberi isyarat era kepastian merupakan puncak pemikiran manusia menuju paham kebebasan dari keterbelengguan kekuasaan yang absolut. Kemapanan teks menjadi pilihan yang tidak dapat dihindari dalam membatasi hasrat ambisius penguasa yang semenamena. Saat itu, perbuatan berwatak jahat atau tidak, bukan ditentukan berdasarkan rasa pasti terlebih lagi harapan keadilan. Selera yang sedang berkuasa membangun asumsi perbuatan tercela sebatas diukur pada tingkat kepatuhan atas kekuasaan. ${ }^{2}$

Keadaan seperti itu didukung oleh ketiadaan pedoman "teks" sebagai standar yang memberikan acuan kepastian. Sehingga muncul pemikiran untuk memformalkan sesuatu yang syarat dengan moral, etika, perintah, larangan, dan sanksi agar dapat bernilai pasti dalam arti konkrit mewujud pada bentuk legalitas teks. Teks hukum bukan barang jadi yang terlepas dari berbagai faktor, baik itu sejarah, kekuasaan, paradigma, kultur, politik, bahkan kehendak untuk mendominasi yang lain. Bila teks hanya diterima dengan kalkulasi objektif dan bebas nilai, maka sejak saat itu teks akan menjadi suatu anomali.

Setidaknya apa yang telah dilakukan oleh Unger dan Kennedy telah membuktikan melalui gerakan studi hukum kritis, bahwa hukum dalam setting Amerika pada waktu itu memberikan tumpangan empuk bagi kapitalisme dan liberalisme. Sehingga praktik hukum hanya berfungsi bagi pendukung dan

${ }^{1}$ Anthon F. Susanto, Dekonstruksi Hukum Eksplorasi Teks dan Model Pembacaan, Genta Publishing, Yogyakarta, 2010, hlm. 7.

${ }^{2}$ Pada zaman Romawi dikenal adanya crime extra ordinaria, yaitu kejahatan-kejahatan yang tidak disebutkan dalam undang-undang. Ketika hukum Romawi Kuno diterima di Eropa Barat pada abad pertengahan, crime extra ordinaria ini diterima oleh raja-raja yang berkuasa dan para raja itu cenderung menggunakan hukum pidana itu sewenangwenang menurut kehendak dan kebutuhannya. Pada zaman itu, sebagian besar hukum pidana tidak tertulis, sehingga dengan kekuasaannya yang sangat absolut raja dapat menyelenggarakan pengadilan dengan sewenang-wenang. Rakyat tidak mengetahui secara pasti, mana perbuatan yang dilarang dan mana perbuatan yang tidak dilarang. Pada saat yang bersamaan muncul para ahli pikir seperti Montesquieu dan JJ. Rousseau yang menuntut agar kekuasaan raja dibatasi dengan undang-undang tertulis. Eddy O.S. Hiariej, Asas Legalitas \& Penemuan Hukum Dalam Hukum Pidana, Penerbit Erlangga, Jakarta, 2009, hlm. 8. 
perputaran sirkuit kapital yang sedang berjalan. ${ }^{3}$ Gerakan studi hukum kritis memposisikan teks hukum merupakan dunia makna, diperlukan kesadaran kritis untuk memahaminya. Makna tidak dapat begitu saja tercermin dalam kumpulan teks, makna harus dibaca dengan kenyataan walaupun sepertinya terlalu rumit. Pekerjaan itu memerlukan keberanian sebagai upaya mengeluarkan kemapanan teks dari kebekuan dan kekakuan.

Dominasi kemapanan teks menjadi penyakit kronis bila tulisan ini memberikan tempat untuk memperbincangkan masa depan ilmu hukum pidana yang bertumpu pada asas fundamentalnya yaitu asas legalitas. Barda Nawawi Arief melihat teks hukum "asas legalitas" dengan perasaan nasionalistik dan kontemplatif. Dengan mengatakan bahwa: “Dengan adanya Pasal 1 KUHP (asas legalitas) itu seolah-olah hukum pidana tidak tertulis yang hidup atau yang pernah ada di masyarakat, sengaja "ditidurkan atau dimatikan". Semasa zaman penjajahan, ditidurkannya hukum pidana tidak tertulis itu masih dapat dimaklumi karena memang sesuai dengan politik hukum Belanda pada saat itu. Namun, akan dirasakan janggal apabila kebijakan itu juga diteruskan setelah kemerdekaan." ${ }^{4}$

Asas legalitas sebagaimana yang termanifestasi dalam KUHP saat ini merupakan selera kultural Belanda, di mana kerangka pikir yang membawa paham individualism dan liberalism. Ringkasnya, asas legalitas tidak saja menjadi acuan menestapakan perbuatan tercela dengan pelbagi sanksi, akan tetapi asas legalitas telah melanggengkan sistem dominasi praktik kultural dengan pertukaran cara berhukum yang sama sekali tidak berangkat dari kultur bangsa Indonesia yang pemaaf, toleran, plural, kekeluargaan, bernurani, religius atau yang lebih berarti adalah jiwa Pancasila.

Berangkat dari paham individualistik, tidak heran KUHP yang berlaku saat ini hanya mengakui asas kepastian hukum, mengingat rasionalitas teks secara tertulis menjadi domain utama dalam menentukan salah-benar suatu perbuatan pidana. Dalam pengertian yang berbeda, hanya hukum pidana tertulis saja yang dapat menentukan mana perbuatan jahat dan tidak jahat. Secara filosofis KUHP saat ini menggenggam asas legalitas dalam pengertian formal, aspek materiel menjadi sesuatu yang tidak terbahas. Konsekuensi dari itu semua, hukum pidana tidak tertulis 'ditidurkan' dan 'dimatikan' oleh asas legalitas di dalam KUHP.

\footnotetext{
${ }^{3}$ Awaludin Marwan, Studi Hukum Kritis dari Modern, Posmodern Hingga Posmarxis, Thafa Media, Yogyakarta, 2012, hlm. 2.

${ }^{4}$ Barda Nawawai Arief, Beberapa Aspek Kebijakan Penegakan dan Pengembangan Hukum Pidana, Citra Aditya Bakti, Bandung, 2005, hlm. 147.
} 
Pada masa transisi kemerdekaan, KUHP Belanda tetap diberlakukan untuk menghindari kekosongan hukum, akan tetapi keberlakuan KUHP diperkenankan sepanjang tidak bertentangan dengan UUD 1945 dan makna kemerdekaan bangsa Indonesia. Di mana induk dari sistem hukum pidana Indonesia (KUHP) tidak dilakukan perubahan tetapi hanya menutupi kekurangan KUHP dengan membuat aturan pidana khusus yang sama sekali tidak menjadi jalan keluar justru hanya memiliki kerancuan teoritis (perubahan dalam ranah teknis bukan subtantif). Dengan tidak adanya perubahan dalam KUHP saat ini pada hakikatnya hukum pidana Indonesia masih tetap dilandaskan pada praktek hukum pidana kolonial dengan selimut dan wajah Indonesia.

Tidaklah berlebihan bila ada upaya untuk membangun politik hukum asas legalitas agar nantinya negara mendapatkan legal policy sebagai wujud dari esensi pilihan hukum yang akan diberlakukan.

Sebagaimana Mahfud MD mengutarakan, bahwa politik hukum yang berisi upaya pembaruan hukum menjadi keharusan ketika bangsa ini telah memproklamirkan diri sebagai bangsa yang merdeka. Proklamasi kemerdekaan telah mengubah tradisi masyarakat dari keadaaan terjajah menjadi masyarakat bebas (merdeka). Tujuan hukum pun harus berubah yaitu menangkap semangat kemerdekaan dengan etos dari penjajahan menjadi kebangsaan. Dengan demikian pembaruan dan penggantian atas hukum-hukum peninggalan zaman penjajahan merupakan bagian penting dari politik hukum nasional. ${ }^{5}$

Memperhatikan upaya politik hukum asas legalitas, sama halnya menampung berbagai dimensi perkembangan aneka masalah hukum pidana Indonesia. Keperluan itu sudah semestinya bukan hanya sekedar menganti pasal-pasal saja di dalam KUHP, melainkan hal yang diubah adalah ide dan konsep yang sesuai pada nilai-nilai sosio-filosofis, sosio-politik, dan sosio-kultural yang hidup di tengah masyarakat bangsa Indonesia.

\section{Rumusan Masalah}

Berdasarkan uraian di atas, permasalahan yang akan dikaji adalah: pertama, apakah yang mendasari untuk dilakukan rekonseptualisasi terhadap asas legalitas hukum pidana Indonesia? Kedua, bagaimana membangun politik hukum asas legalitas berdasarkan pada kondisi sosial masyarakat Indonesia saat ini ?

${ }^{5}$ Moh. Mahfud MD, Politik. Hukum di Indonesia, Rajawali Pers, Jakarta, 2012, hlm. 17. 


\section{Tujuan Penelitian}

Adapun tujuan penelitian ini adalah: pertama, untuk mengkaji dan mengungkap alasan yang mendasari rekonseptualisasi terhadap asas legalitas hukum pidana Indonesia. Kedua, untuk memberikan kontribusi terhadap otentifikasi politik hukum asas legalitas yang dibangun berdasarkan nilai-nilai nasional yang utama yaitu sesuai kondisi sosial masyarakat Indonesia.

\section{Metode Penelitian}

Penelitian ini merupakan penelitian hukum normatif, yaitu penelitian yang dilakukan dengan mendasarkan pada kepustakaan dan bahan hukum sekunder. Seperti, Kitab Undang-Undang Hukum Pidana dan Rancangan Kitab UndangUndang Hukum Pidana. Bahan-bahan hukum yang telah dikelompokkan dan diklasifikasikan, selanjutnya dianalisis dengan menggunakan analisis kualitatif. Dengan analisis kualitatif tersebut, maka analisis dalam tulisan ini akan bertumpu pada studi tekstual yaitu mengarahkan kerangka teoretik dalam menganalisis konseptualisasi asas legalitas dalam membangun politik hukum pidana nasional di masa yang akan datang. Dengan berbekal pijakan teoretik tersebut, maka fokus permasalahan membangun politik hukum asas legalitas nantinya akan di jelaskan dengan konsep prismatika hukum dan ide dasar keseimbangan monodualistik.

\section{Hasil Penelitian dan Pembahasan}

\section{Dasar Rekonseptualisasi Asas Legalitas}

Asas legalitas merupakan karya monumental yang diciptakan oleh Paul Johan Anslem von Feuerbach seorang ilmuan hukum pidana Jerman (1775-1833). ${ }^{6}$ Apa yang dirumuskan oleh Feuerbach dalam istilah latin nullum delictum nulla poena sine praevia lege poenali, yang dapat diartikan dalam bahasa Indonesia "tidak ada delik, tidak ada pidana tanpa ketentuan pidana yang mendahuluinya". Sering juga digunakan istilah latin nulum crimen sine lege stricta yaitu "tidak ada delik tanpa ketentuan yang tegas". ${ }^{7}$

\footnotetext{
${ }^{6}$ Eddy O.S. Hiariej, Op. Cit., hlm. 7.

${ }^{7}$ Andi Hamzah, Asas-Asas Hukum Pidana, Rineka Cipta, Jakarta, 2008, hlm. 39-40.
} 
Menurut Hazewinkel-Suringa, pemikiran seperti apa yang terkandung dalam asas legalitas itu ditemukan juga dalam ajaran Montesquieu mengenai ajaran pemisahan kekuasaan, bukan hakim yang menyebutkan apa yang dapat dipidana, pembuat undang-undang menciptakan hukum. Pembuat undang-undang tidak saja menetapkan norma tetapi juga harus diumumkan sebelum perbuatan. ${ }^{8}$

Asas legalitas secara historis merupakan reaksi terhadap kesewenang-wenangan penguasa di zaman Ancien Regime serta jawaban atas kebutuhan fungsional terhadap kepastian hukum yang menjadi keharusan di dalam suatu negara hukum liberal pada waktu itu. ${ }^{9}$ Jika dilihat dari situasi dan kondisi lahirnya asas legalitas, sulitlah dinafikan bahwa ajaran tersebut ditujukan untuk melindungi kebebasan dan kepentingan individu. Sebagaimana apa yang dikatakan oleh Barda Nawawi Arief bahwa; KUHP (WvS) warisan Belanda dilatarbelakangi oleh pemikiran/paham individualisme-liberalisme dan sangat dipengaruhi oleh aliran klasik, walaupun ada juga pengaruh aliran neo-klasik.

Aliran klasik ${ }^{10}$ menjadikan paham pembalasan sebagai dalih pemidanaan. Hukum pidana menjadi bersifat retributif dan represif. Aliran klasik berpaham indeterminisme mengenai kebebasan kehendak manusia yang berfokus pada perbuatan pelaku kejahatan sehingga dikehendaki hukum pidana pada perbuatan dan bukan pada pelakunya. ${ }^{11}$

Menurut Groenhuijsen, ada empat makna yang terkandung dalam asas legalitas. Pertama, bahwa pembuat undang-undang tidak boleh memberlakukan ketentuan pidana berlaku mundur. Kedua, bahwa semua perbuatan yang dilarang harus dimuat dalam rumusan delik sejelas-jelasnya. Ketiga, hakim dilarang menyatakan bahwa terdakwa melakukan perbuatan pidana didasarkan atas hukum tidak tertulis atau hukum kebiasaan, dan keempat, terhadap peraturan hukum pidana dilarang diterapkan analogi. ${ }^{12}$

\footnotetext{
${ }^{8}$ Ibid.

${ }^{9}$ Komariah Emong Sapardjaja, Ajaran Sifat Melawan Hukum Materiel Dalam Hukum Pidana Indonesia, Alumni, Bandung, 2002, hlm. 6.

${ }^{10}$ Aliran klasik ini lahir sebagai reaksi terhadap ancient regime yang arbitrair pada abad ke-18 di Prancis, yang banyak menimbulkan ketidakpastian hukum, ketidaksamaan dalam hukum, dan ketidakadilan. Aliran ini menghendaki hukum pidana tersusun secara sistematis dan bertitik berat pada kepastian hukum. tujuan hukum pidana adalah untuk melindungi kepentingan individu dari kesewenang-wenangan penguasa. Dalam sistem pemidanaan, aliran klasik pada prinsipnya hanya menganut single track system, yakni sistem sanksi tunggal, berupa jenis sanksi pidana. Sistem pemidanaan aliran klasik ini lalu melahirkan teori absolut dengan paham pembalasan sebagai legitimasi pemidanaan. Eddy O.S. Hiariej, Op. Cit., hlm. 10.

${ }^{11}$ Ibid.
} 
Dalam menetapkan sumber hukum atau dasar patut dipidananya suatu perbuatan bertolak pada asas legalitas dalam pengertian formal. Sumber hukum utamanya ialah kepastian undang-undang. ${ }^{13}$ Dapatlah dikatakan bahwa asas legalitas WvS saat ini hanya mengantur ajaran sifat melawan hukum formal.

Pada intinya, ide dasar yang ingin diwujudkan dalam konsep (RUU) KUHP berorientasi pada ide/asas kesimbangan, yang antara lain mencakup; ${ }^{14} 1$ ) Keseimbangan monodualistik antara kepentingan umum/masyarakat dan kepentingan individu/perorangan; 2) Keseimbangan antara perlindungan/ kepentingan pelaku dan korban; 3) Keseimbangan antara perbuatan dan orang; ide daad-dader strafrecht; 4) Keseimbangan antara kriteria formal dan materiel; 5) Keseimbangan antara kepastian hukum dan keadilan; 6) Keseimbangan antara social welfare dengan social defence; 7) Keseimbangan antara sanksi pidana dan tindakan; 8) Keseimbangan antara pemidanaan dan pemaafan hakim (rechterlijk pardon).

Politik hukum adalah "legal policy atau garis (kebijakan) resmi tentang hukum yang akan diberlakukan baik dengan pembuatan hukum baru maupun dengan penggantian hukum lama, dalam rangka mencapai tujuan negara" ${ }^{15}$ Dengan demikian politik hukum merupakan pilihan tentang hukum yang akan diberlakukan di masa yang akan datang.

Sebagaimana sumber politik hukum nasional didasarkan oleh dua alasan. Pertama, Pembukaan dan Pasal-pasal UUD 1945 memuat tujuan, dasar, dan cita hukum. Kedua, Pembukaan dan Pasal-pasal UUD 1945 mengandung nilai yang bersumber dari pandangan dan budaya bangsa. Jika dikaitkan dengan literatur tentang kombinasi antara lebih dari satu pilihan nilai sosial, disebut sebagai pilihan nilai prismatik yang karenanya dalam konteks hukum dapat disebut sebagai hukum prismatik. ${ }^{16}$

Konsep prismatika hukum (keseimbangan nilai yang baik) adalah mengambil spirit keseimbangan individualisme dan kolektivisme, rechtsstaat dan the rule of law, alat pembangunan dan cermin keadaan masyarakat, serta negara agama dan negara sekuler. Jika dilihat dari situasi dan kondisi lahirnya asas legalitas, sulitlah dinafikan bahwa ajaran tersebut ditujukan untuk melindungi nilai kebebasan dan kepentingan

\footnotetext{
${ }^{13}$ Barda Nawawi Arief, Bunga Rampai Kebijakan Hukum Pidana, Citra Aditya Bakti, Bandung,1996, hlm. 88.

${ }^{14}$ Barda Nawawi Arief, Perkembangan Asas-Asas Hukum Pidana Indonesia (Perspektif Perbandingan Hukum Pidana), Badan Penerbit UNDIP, Semarang, 2012, hlm. 24.

${ }^{15}$ Moh. Mahfud MD, Politik Hukum, Op. Cit., hlm. 1.

${ }^{16}$ Moh. Mahfud MD, Membangun Politik Hukum, Menegakekan Konstitusi, Rajawali Pers, Jakarta, 2012, hlm. 23.
} 
individu. Sebagaimana KUHP warisan Belanda dilatarbelakangi oleh pemikiran/ paham individualisme-liberalisme dan sangat dipengaruhi oleh aliran klasik. Aliran klasik berpaham indeterminisme mengenai kebebasan kehendak manusia yang berfokus pada perbuatan pelaku kejahatan sehingga dikehendaki hukum pidana pada perbuatan dan bukan pada pelakunya.

Atas dasar itu, nilai kebebasan dalam anggapan paham individualistik hanya dapat terwujud ketika dijamin oleh sistem hukum yang rigid, rasional, tertulis, dan bersifat pasti. Sehingga paham ini kemudian menjelma masuk ke dalam asas legalitas yang menuntut adanya kodifikasi secara formal terhadap kualifikasi perbuatan pidana.

Pengaruh kodifikasi dan sifat mengagungkan undang-undang tampak dengan dianutnya ajaran sifat melawan hukum formal dalam asas legalitas KUHP. Ajaran yang mengatakan bahwa suatu tindak pidana telah terjadi apabila telah terpenuhi unsur-unsur seperti yang termuat dalam lukisan delik atau disertai akibat-akibatnya. Dengan perkataan lain, perbuatan melawan hukum adalah sama dengan bertentangan dengan undang-undang.

Hasil tersebut menunjukkan seperti tidak ada tempat bagi hukum yang tidak tertulis (kebiasaan) bila melihat keberlakuan ajaran sifat melawan hukum formal. Bahkan terlebih lagi, ajaran tersebut berorientasi pada perbuatan pidana semata, dengan maksud pidana sebagai alat pembalasan dalam menestapakan perbuatan tercela. Ajaran yang begitu formalistik lebih mendahulukan prinsip legalitas ketimbang prinsip manusia dan kemanusiaan. Bahkan ajaran itu hanya memikirkan akibat dari perbuatan ketimbang menyuguhkan solusi mengapa dan apa latarbelakang suatu perbuatan tercela itu hadir, serta bagaimana pula memutus mata rantai akar persoalan itu.

Asas legalitas dengan sifat ajaran melawan hukum formal mendapat gugatan dalam kenyataannya. Sejarah perhelatan ilmu hukum pidana telah melahirkan yurisprudensi pertama tentang ajaran sifat melawan hukum materiel ${ }^{17}$ pada tahun 1933 (Arrest Hoge Raad, 20 Februari 1933, yang terkenal dengan nama Veaarts arrest),

${ }^{17}$ Ajaran sifat melawan hukum materiel dalam doktrin hukum pidana diterima dalam fungsinya yang negatif dan positif. Ajaran sifat melawan hukum materiel dalam fungsinya yang negatif bahwa suatu perbuatan dapat hilang sifat sebagai melawan hukum apabila secara materiel perbuatan itu tidak bertentangan dengan hukum. Sebaliknya Ajaran sifat melawan hukum materiel dalam fungsinya yang positif bahwa suatu perbuatan dapat dikatakan sebagai pidana bila perbuatan itu secara materiel bertentangan dengan hukum, sekalipun dalam ketentuan undang-undang tertulis tidak mengaturnya. 
membuktikan bahwa penerapan ajaran sifat melawan hukum formal tidak cukup memberikan jaminan terhadap penemuan keadilan dalam peristiwa kasus konkrit yang dihadapinya. ${ }^{18}$ Yurisprudensi Veaarts arrest merupakan bukti secara perlahan paham legisme mendapat perlawanan. Ajaran sifat melawan hukum secara formal membunuh akal sehat hakim untuk berfikir kritis di luar teks undang-undang. Hakim menjadi serba corong undang-undang. Pada akhirnya hakim seperti itu menerima hukum sebagai skema yang final.

Dominasi paham legisme yang membuat hakim hanya terjebak pada kepastian undang-undang mendapat perhatian serius di dalam upaya politik hukum pidana nasional ke depan. Bahwa konsep (RUU) KUHP tetap mempertahankan asas legalitas dalam pengertian yang formal (hukum tertulis), namun yang paling fundamental adalah terdapat perubahan memperluas perumusannya secara materiel dengan menegaskan asas legalitas dalam arti formal itu tidak mengurangi berlakunya "hukum yang hidup" di dalam masyarakat (hukum tidak tertulis). ${ }^{19}$

Perlu dikemukakan, bahwa Utrecht termasuk pemikir yang memberikan pertimbangan kritis terhadap pemberlakuan asas legalitas di Indonesia. Utrecht mengatakan asas legalitas dapat berpotensi menghalangi berlakunya hukum pidana adat yang masih hidup dan akan selalu hidup dalam masyarakat Indonesia. ${ }^{20}$ Dalam pendapat yang berbeda bahwa Kelsen mengukuhkan prinsip asas legalitas dengan ajaran melawan hukum secara formal merupakan ekspresi nyata dari legal positivism dalam hukum pidana. ${ }^{21}$

Riwayat perjalanan penyusunan RUU KUHP sudah berjalan 48 tahun. Inisiatif itu berawal dari adanya rekomendasi Seminar Nasional I tahun 1963 yang menyerukan agar rancangan kodifikasi hukum pidana nasional segera mungkin diselesaikan. ${ }^{22}$ Seminar tersebut menghendaki dalam KUHP baru pada bagian

${ }^{18}$ Komariah Emong Sapardjaja, Op. Cit., hlm. 18. Arrest ini memberikan kelonggaran kepada hakim untuk memberikan keadilan kepada orang yang tidak melakukan tindak pidana (seperti yang dituduhkan dalam dakwaan Jaksa) dengan jalan menyatakan hilangnya sifat melawan hukum secara formal berdasarkan alasan-alasan di luar undangundang pidana, yaitu hukum tidak tertulis, yang dalam perkara khusus ini adalah: pertimbangan yang secara ilmiah dianggap dapat dibenarkan. Akan tetapi ajaran sifat melawan hukum materiel tidak bertahan lama di Belanda dan tak pernah diterapkan lagi dalam putusan-putusan di penggadilan.

${ }^{19}$ Barda Nawawi Arief, Bunga Rampai... Op. Cit., hlm. 88. Patut dicatat, bahwa berlakunya hukum yang hidup dimasyarakat itu hanya untuk delik-delik yang tidak ada bandingnya (persamaannya) atau tidak telah diatur di dalam undang-undang. Bahwa berlakunya hukum yang hidup di masyarakat harus sesuai dengan nilai-nilai pancasila dan prinsip-prinsip umum yang diakui oleh masyarakat.

${ }^{20}$ Andi Hamzah, Op. Cit., hlm. 41.

${ }^{21}$ Eddy O.S. Hiariej, Op. Cit., hlm. 10.

${ }^{22}$ Barda Nawawi Arief, RUU KUHP Baru (Sebuah Restrukturisasi/Rekonstruksi Sistem Hukum Pidana Indonesia, Badan Penerbit UNDIP, Semarang, 2012, hlm. 27. 
umum yang memuat asas-asas umum (fundamental) antara lain asas legalitas hendaknya disusun secara progresif sesuai dengan kepribadian Indonesia dan perkembangan revolusi. ${ }^{23}$ Atas dasar tersebut, riwayat singkat penyusunan konsep RUU KUHP dapat diuraikan sebagai berikut. ${ }^{24}$ Dilihat dari ruang lingkup materi: Periode ke-1 (1954-1976), menyusun Buku I (Aturan Umum), dalam periode ini menghasilkan Konsep Buku I tahun 1964, 1968, 1971, dan 1972. Selanjutnya pada periode ke-2 (1977-1978) dengan agenda menyusun Buku II (Kejahatan) dan Buku III (Pelanggaran). Periode ini menghasilkan BAS 1977. Periode ke-3 (1979-2010) dengan agenda menyusun kodifikasi dalam 2 (dua) buku, menggabungkan Buku I (Aturan Peralihan) dan Buku II (Tindak Pidana). Periode ini menghasilkan konsep RUU KUHP dari tahun 1979-2012.

Dilihat dari proses/tahap penyusunan, periode konsep LPHN/BPHN: periode ini dapat disebut "periode pengkajian dan penyusunan konsep rancangan KUHP pada waktu itu dibentuk 2 Tim, yaitu Tim Pengkajian dan Tim Penyusunan KUHP. Periode konsep Direktorat KUMDANG \& Dirjen PP: periode ini dapat disebut " periode Penyususnan RUU KUHP”. Dilihat dari penyusunan secara ilmiah, seminar, lokakarya, semiloka, kajian di berbagai fakultas/universitas. Kajian/penelitian hukum adat, kajian perundang-undangan di luar KUHP, dan kajian komparasi (termasuk diskusi dengan para ahli hukum Belanda serta kajian dokumen Internasional).

\section{Membangun Politik Hukum Asas Legalitas}

Ikhtiar membangun politik hukum asas legalitas merupakan bagian yang tidak dapat dipisahkan dari penyusunan konsep RUU KUHP. Membangun dalam bahasan ini diartikan untuk memperbaharui/menciptakan "rancang bangun" sistem baru. Maka pembahasan perubahan RUU KUHP idealnya bukan sekedar membahas masalah perumusan/formulasi pasal (UU), melainkan hakikatnya membangun adalah menentukan pilihan-pilihan hukum yang merupakan kristalisasi dari pemikiran/konsep/ide dasarnya. Oleh karena itu, rekonseptualisasi asas legalitas akan di arahkan pada pembaharuan nilai berdasarkan kondisi sosial budaya masyarakat Indonesia.

\footnotetext{
${ }^{23}$ Barda Nawawi Arief, Kumpulan Hasil Seminar Hukum Nasional Ke I s/ d VIII dan Konvensi Hukum Nasional 2008 Tentang Undang-Undang Dasar 1945 Sebagai Landasan Konstitusional Grand Design Sistem dan Politik. Hukum Nasional, Badan Penerbit Universitas Diponegoro, Semarang, 2011, hlm. 6.

${ }^{24}$ Barda Nawawi Arief, RUU KUHP, Op. Cit., hlm. 30-32.
} 
Berdasarkan apa yang sudah diuraikan pada bagian sebelumnya, bahwa asas legalitas KUHP Belanda cenderung mewakili tradisi hukum civil law (hukum tertulis). Konstruksi hukum yang dibangun adalah legal positivistik sebab otoritas perbuatan pidana hanya bersandarkan pada hukum tertulis dengan menegakkan nilai kepastian hukum. Sehingga corak asas legalitas yang terkandung di dalamnya berorientasi pada perbuatan (orang/pelaku tindak pidana). Di samping itu, sosok asas legalitas merupakan kristalisasi dari nilai individualisme-liberalisme yang dipengaruhi oleh aliran klasik. Paham indeterminisme menjadi sesuatu yang agung bagi aliran klasik. Di mana kebebasan kehendak manusia yang berfokus pada perbuatan pelaku kejahatan. Maka kehendak bebas manusia itu akan berhadapan dengan rezim hukum pidana yang berorientasi pada pembalasan sebagai dalih pemidanaan. Dalam konteks ini, hukum pidana menjadi bersifat retributif dan represif.

Di samping itu, dalam aspek sanksi, asas legalitas Belanda hanya menitikberatkan pemidanaan yaitu menjatuhkan sanksi pidana tanpa adanya sanksi tindakan. Perkembangan aneka masalah hukum pidana yang begitu kompleks, tentu akan merubah cara pandang keilmuan hukum pidana dalam melihat perbuatan pidana. Sehingga hukum pidana melalui asas legalitas ke depan tidak kaku akan tetapi fleksibel. Orientasi putusan pengadilan tidak saja berakhir pada pemidanaan tapi bisa juga pemaafan.

Bertolak dari pemikiran di atas, maka penyusunan konsep KUHP (baru) tidak dapat dilepaskan dari ide/kebijakan pembangunan Sistem Hukum Nasional yang berlandaskan Pancasila sebagai nilai-nilai berkehidupan kebangsaan yang dicita-citakan. Ini berarti, politik hukum Pidana Nasional seharusnya juga dilatarbelakangi dan bersumber/berorientasi pada ide-ide dasar ("basic ideas") Pancasila yang mengandung di dalamnya keseimbangan nilai/ide/paradigma, yaitu; moral religius (Ketuhanan), kemanusiaan (humanistik), kebangsaan, demokrasi, dan keadilan sosial. Di mana keseimbangan lima sila itu dapat menjadi keseimbangan tiga pilar', yaitu; pilar Ketuhanan (religius), pilar Kemanusiaan (humanistik, dan pilar Kemasyarakatan (kebangsaan, nasionalistik; demokrasi/kerakyatan; dan keadilan sosial). ${ }^{25}$

Untuk keperluan itu dominasi asas legalitas warisan kolonial mesti disusun dan diformulasikan dengan apa yang disebut oleh Barda Nawawi Arief berorientasi

${ }^{25}$ Barda Nawawi Arief, Pembaharuan Hukum Pidana Dalam Perspektif Kajian Perbandingan, Citra Aditya Bakti, Bandung, 2011, hlm. 4. 
pada pokok pemikiran "ide dasar keseimbangan" dan diwujudkan dalam ketiga permasalahan pokok hukum pidana, yaitu masalah "tindak pidana'”, masalah "kesalahan/pertanggung jawaban pidana", dan masalah "pidana dan pemidanaan".

Ide dasar keseimbangan ini merupakan pilihan hukum yang bisa saja kita sebut memiliki konsep prismatik (nilai keseimbangan yang baik). Mengingat ide dasar keseimbangan mengidentifikasi pilihan kombinatif atas nilai-nilai yang ada di tengah masyarakat Indonesia.

Seperti adagium yang dikemukakan Mahfud MD, bahwa "politik hukum nasional harus dapat mendorong dan mengisi semua unsur di dalam sistem hukum nasional agar bekerja sesuai dengan cita-cita bangsa, tujuan negara, cita hukum, dan kaidah penuntun hukum di Indonesia sebagaimana yang terkandung dalam pembukaan UUD 1945.

Prismatika hukum asas legalitas sebuah gagasan politik hukum yang dapat kita katakan khas Indonesia. Tidak berlebihan bila apa yang diungkapkan oleh Barda melalui ide dasar keseimbangan serta konsep prismatika hukum yang dilontarkan oleh Mahfud MD merupakan gagasan teoretik dapat meletakkan pelbagai kombinasi nilai yang mana terpancarkan dari kultur bangsa Indonesia, dalam arti formal Pembukaan UUD 1945 dan Pancasila.

Prismatika hukum asas legalitas dalam membangun sistem hukum pidana Indonesia ke depan merupakan penjabaran dari kristalisasi tujuan, dasar, dan citacita bangsa yang berpijak pada nilai kepentingan individualisme dan kolektivisme (keseimbangan monodualistik), menegakkan negara hukum rechtsstaat dan the rule of law (keseimbangan formal dan material), serta perpaduan hukum sebagai alat perubahan masyarakat dan hukum sebagai cermin keadaan masyarakat (keseimbangan social welfare dan social defence).

Secara lebih tegas prismatika hukum asas legalitas akan memberikan legal policy atau garis kebijakan yang diberlakukan oleh negara mengenai sistem hukum pidana yang bersumber dari dan berorientasi pada keseimbangan lima sila dalam Pancasila, yang dapat dipadatkan menjadi "keseimbangan tiga pilar", yaitu; pilar ketuhanan (religius), pilar kemanusiaan (humanistik) dan pilar kemasyarakatan (kebangsaan, demokrasi, dan keadilan sosial).

Pilihan hukum itu akan menjadi bagian penting dalam merekonseptualisasi asas legalitas dalam RUU KUHP, di mana memformulasikan perbuatan pidana tidak semata merugikan orang lain dalam arti kepidanaan tetapi juga bertentangan dengan moral-etik keagamaan serta nilai yang hidup di masyarakat. 
Di samping itu juga, politik hukum asas legalitas ke depan diharapkan berwatak humanistik, di mana pilar kemanusiaan menjadi bagian penting. Asas legalitas dalam KUHP Belanda tidak dapat dikatakan sepenuhnya benar hanya berwatak retributif (pembalasan). Dalam kenyataannya, bangsa ini sering dihadapkan dengan berbagai peristiwa pidana yang menurut nalar sosial tidak adil. Sebut saja salah satu kasus yang menimpa Mbok Minah. Perbuatan pencurian kakao yang dilakukan oleh Mbok Minah secara pidana memenuhi unsur pasal pencurian, akan tetapi bila dilihat dari sisi kemanusiaan dan aspek lainnya, apakah benar hukum pidana Indonesia dalam segala hal ketika berhadapan dengan unsur pidana mesti berakhir pemidanaan.

Untuk itu, asas legalitas di masa yang akan datang, harus berani keluar dari tradisi legalistik formal yang demikian. Harus ada mekanisme yang diciptakan berangkat dari nilai humanitas di mana orientasi berfikirnya bukan lagi melulu penghakiman pada perbuatan akan tetapi juga memperhatikan aspek restoratif terhadap korban begitu juga pelaku. Dalam hal ini konsep pemaafan yang diberikan oleh hakim (rechterlijk pardon) merupakan pilihan hukum yang tepat dan berwatak humanis.

Pada ranah yang lebih teoritis, dimana kerancuan fundamental dalam asas legalitas KUHP Belanda yang berlaku saat ini mematikan dan menidurkan hukum tidak tertulis yang hidup di masyarakat. Sejatinya pengakuan hukum tidak tertulis mesti berada pada tempat yang kokoh dalam hukum pidana induknya, bukan berada di luar KUHP. Demi kepentingan itu, politik hukum asas legalitas mesti memberi tempat nilai nasionalistik hukum Indonesia, di mana hukum tidak tertulis merupakan kondisi hukum bangsa Indonesia yang sebenarnya. Ia berada pada ruang sosial masyarakat yang bersifat alamiah. Selebihnya adalah tugas kita bersama untuk mencari tolak ukur keberlakuan hukum pidana tidak tertulis dapat dijadikan sebagai dasar pemidanaan. Paling tidak konsep RUU KUHP yang ada saat ini sudah cukup baik memposisikan hal tadi, tetap mempertahankan asas legalitas dengan tidak mengurangi berlakuanya hukum yang hidup di tengah masyarakat sepanjang dapat dikatakan tidak bertentangan dengan Pancasila.

\section{Penutup}

Berdasarkan pembahasan di atas, maka diperoleh kesimpulan berupa: pertama, dianutnya ajaran sifat melawan hukum formal dalam asas legalitas KUHP yakni 
ajaran yang mengatakan bahwa suatu tindak pidana telah terjadi apabila telah terpenuhi unsur-unsur seperti yang termuat dalam lukisan delik atau disertai akibatakibatnya, menunjukkan tidak ada tempat bagi hukum yang tidak tertulis (kebiasaan) bila melihat keberlakuan ajaran sifat melawan hukum formal. Bahkan terlebih lagi, ajaran tersebut berorientasi pada perbuatan pidana semata, dengan maksud pidana sebagai alat pembalasan dalam menestapakan perbuatan tercela. Kedua, untuk membangun politik hukum asas legalitas berdasarkan pada kondisi sosial masyarakat Indonesia saat ini diperlukan gagasan, konsep, nilai, dan ide keseimbangan, sebagai 'sokongan' yang berarti dalam melakukan upaya politik hukum asas legalitas dengan tawaran konsep prismatik (nilai keseimbangan yang baik). Dimana prismatika hukum asas legalitas bersumber dari dan berorientasi pada keseimbangan lima sila dalam Pancasila, yang dapat dipadatkan menjadi "keseimbangan tiga pilar", yaitu; pilar ketuhanan (religius), pilar kemanusiaan (humanistik) dan pilar kemasyarakatan (kebangsaan, demokrasi, dan keadilan sosial).

\section{Daftar Pustaka}

Arief, Nawawai Barda, Bunga Rampai Kebijakan Hukum Pidana, Citra Aditya Bakti, Bandung, 1996.

- Beberapa Aspek Kebijakan Penegakan dan Pengembangan Hukum Pidana, Citra Aditya Bakti, Bandung, 2005.

, Kumpulan Hasil Seminar Hukum Nasional Ke I s/d VIII dan Konvensi Hukum Nasional 2008 Tentang Undang-Undang Dasar 1945 Sebagai Landasan Konstitusional Grand Design Sistem dan Politik Hukum Nasional, Badan Penerbit Universitas Diponegoro, Semarang, 2011.

- Pembaharuan Hukum Pidana Dalam PerspektifKajian Perbandingan, Citra Aditya Bakti, Bandung, 2011.

, RUU KUHP Baru (Sebuah Restrukturisasi/Rekonstruksi Sistem Hukum Pidana Indonesia, Badan Penerbit UNDIP, Semarang, 2012.

, Perkembangan Asas-Asas Hukum Pidana Indonesia (PerspektifPerbandingan Hukum Pidana), Badan Penerbit UNDIP, Semarang, 2012.

Hamzah, Andi, Asas-Asas Hukum Pidana, Rineka Cipta, Jakarta, 2008.

Hiariej, Eddy O.S., Asas Legalitas \& Penemuan Hukum Dalam Hukum Pidana, Penerbit Erlangga, Jakarta, 2009.

MD, Moh. Mahfud, Demokrasi dan Konstitusi di Indonesia (Studi Tentang Integrasi Politik dan Kehidupan Ketatanegaraan), Rineka Cipta, Jakarta, 2003. 
Politik Hukum di Indonesia, Rajawali Pers, Jakarta, 2012.

, Membangun Politik Hukum, Menegakkan Konstitusi, Rajawali Pers, Jakarta, 2012.

Marwan, Awaludin, Studi Hukum Kritis dari Modern, Posmodern Hingga Posmarxis, Thafa Media, Yogyakarta, 2012.

Rahardjo, Satjipto, Biarkan Hukum Mengalir "Catatan Kritis Tentang Pergulatan Manusia dan Hukum", Penerbit Buku Kompas, Jakarta, 2007.

Sapardjaja, Komariah Emong, Ajaran Sifat Melawan Hukum Materiel Dalam Hukum Pidana Indonesia, Alumni, Bandung, 2002.

Susanto, F. Anthon, Dekonstruksi Hukum Eksplorasi Teks dan Model Pembacaan, Genta Publishing, Yogyakarta, 2010. 